\title{
STRATEGI PENGEMBANGAN SUBSEKTOR PERIKANAN DI KABUPATEN MALUKU TENGGARA BARAT, PROPINSI MALUKU
}

\author{
Yoseph Reressy \\ Leonardus R. Rengkung \\ Theodora M. Katiandagho
}

\begin{abstract}
The objective of the study is: Analyzing a good strategy in the development of the Fisheries Resources in West Southeast Maluku District, so as to provide a decent income for communities and regions. This research is done by using the method of SWOT Analysis (Strengths, Weaknesses, Opportunities, Threats) by looking at internal and external factors that exist. The research results indicate that internal factors, which become the strengths in the management of the fishery sector are the potential of Natural Resources, the availability of a reliable workforce, the potential of the sea in West Southeast Maluku District, improving the management of natural resources in the field of fisheries, and policies of the Government of the district in managing fishery sector. While the weakness of the internal factors are quality of human resources that are still relatively low, lack of education for the workers, the availability of infrastructure, lack of good understanding in technology, and lack of support from formal and informal institutions. External factors which become opportunity are regional autonomy, national policy for marine, support from the central government, and market potential. While the threats of external factors are the condition of the natural, social and cultural, illegal fishing, the limited supply of energy, and the price of the product which is not stable. In short, to improve the good management of the fishery sector in West Southeast Maluku District, then through a SWOT analysis, all elements of society in the district, especially the local government should optimize its strengths and opportunities that exist, as well as seeking alternative policies to reduce its weaknesses and threats which exist.
\end{abstract}

Keywords: fishery sector, SWOT Analysis, Internal and External factors, Moluccas Province

Abstrak

Tujuan dilaksanakannya penelitian adalah: Menganalisis strategi yang baik dalam pengembangan Sumber Daya Perikanan yang di Kabupaten Maluku Tenggara Barat, sehingga dapat memberikan pendapatan yang layak bagi masyarakat dan daerah. Penelitian ini dilakukan dengan menggunakan metode analisis SWOT (Strengths, Weaknesses, Opportunities, Threats) dengan melihat faktor internal dan eksternal yang ada. Hasil penelitian ini menunjukkan bahwa faktor internal yang menjadi kekuatan dalam pengelolaan sektor perikanan adalah: potensi Sumber Daya Alam, ketersediaan tenaga kerja yang handal, potensi laut di Kabupaten Maluku Tenggara Barat, meningkatkan pengelolaan Sumber Daya Alam di bidang perikanan dan kebijakan Pemerintah Daerah Maluku Tenggara Barat dalam pengelolaan subsektor perikanan. Sedangkan faktor internal yang menjadi kelemahan adalah: kualitas sumber daya manusia yang relatif masih rendah, kurang adanya penyuluhan dari para petugas lapangan, ketersediaan sarana dan prasarana, kurang adanya pemahaman yang baik tentang teknologi, dan kurang adanya dukungan dari lembaga forma dan informal. Faktor eksternal yang menjadi peluang adalah otonomi daerah, kebijakan nasional untuk kelautan, dukungan pemerintah pusat, dan potensi pasar. Sedangkan faktor eksternal yang menjadi ancaman adalah: kondisi alam, sosial budaya masyarakat, pencurian ikan, terbatasnya pasokan energy dan harga produk yang tidak stabil. Dengan demikian, untuk meningkatkan pengelolaan yang baik terhadap sektor perikanan di Kabupaten Maluku Tenggara Barat, maka melalui analisis SWOT, semua elemen masyarakat di daerah, khususnya pemerintah daerah harus mengoptimalkan kekuatan dan peluang yang ada sekaligus mencari alternatif kebijakan dalam mengurangi kelemahan dan ancaman yang ada.

Kata Kunci: Sektor Perikanan, Analisis SWOT, Faktor Internal dan Eksternal, Provinsi Maluku 


\section{PENDAHULUAN}

\section{Latar Belakang}

Pengembangan wilayah dengan melihat potensi-potensi yang ada di wilayahwilayah merupakan suatu hal yang sangat baik dalam pengembangan suatu wilayah, baik potensi Sumber Daya Manusia (SDM) maupun potensi Sumber Daya Alam (SDA) yang ada. Kabupaten Maluku Tenggara Barat ini memiliki potensi yang begitu besar pada sektor pertanian khususnya pada subsektor perikanan yang boleh dikatakan sangat menjanjikan dalam pengembangan daerah serta dapat meningkatkan kesejahteraan masyarakat. Pengembangan pada sektor perikanan merupakan sesuatu yang sangat penting, karena sektor perikanan dapat memberikan kontribusi yang besar dalam meningkatkan kesejahtraan hidup masyarakat yang ada di Kabupaten Maluku Tenggara Barat, sehingga dapat meningkatkan pengembangan kapabilitas dan kebutuhan (Rustiadi, Sunsun dan Panuju, 2011).

Faktor utama yang mempengaruhi perkembangan perekonomian wilayah yaitu Sumber Daya Alam, tersedianya Sumber Daya Alam yang melimpah merupakan hal yang penting dalam pengembangan wilayah (Jhingan, 2013). Potensi yang ada di laut Kabupaten Maluku Tenggara Barat sangat menjanjikan dalam meningkatkan kesejahteraan masyarakat setempat, dengan begitu maka potensi-potensi yang ada perlu untuk diolah semaksimal mungkin. Namun dalam peningkatan dan pengolahan sumber daya alam lebih khusus sumber daya perikanan dan kelautan belum dilakukan dengan maksimal. Hal ini disebabkan kurangnya sarana dan prasarana penunjang dan kualitas sumber daya manusia yang masih terbatas.

\section{Konsep Wilayah dan Pengembangan Wilayah}

Pengembangan wilayah merupakan suatu proses yang sangat bersifat positif, karena dengan adanya pengembangan wilayah maka suatu wilayah akan berkembangan dan adanya keseimbangan, sehingga daerah tersebut akan menuju pada suatu kesejahteraan. Pengembangan wilayah diartikan sebagai berbagai kegiatan (dalam bentuk implementasi dari kebijakan dan perencanaan) pembangunan yang dilaksanakan di atas suatu permukaan bumi (daratan dan perairan), yang selanjutnya disebut sebagai wilayah (Adisamita, 2014).

Menurut Rustiadi (2011) wilayah dapat didefinisikan sebagai unit geografis dengan batas-batas spesifik tertentu dimana komponen-komponen wilayah tersebut satu sama lain saling berinteraksi secara fungsional, sehingga batasan wilayah tidaklah selalu bersifat fisik dan pasti tetapi seringkali bersifat dinamis. Myrdal pada era 1950-an muncul dengan teori yang menjelaskan hubungan antara wilayah maju dan wilayah belakangnya dengan menggunakan istilah backwash and spread effect (Sumarni, 2012). Sedangkan Friedmann (era 1960-an) yang lebih menekankan pada pembentukan hierarki guna mempermudah pengembangan sistem pembangunan yang kemudian dikenal dengan teori pusat pertumbuhan, namun Parr (1999) berpendapat bahwa perkembangnan wilayah selalu disertai dengan perubahan-perubahan (Nugroho dan Dahuri, 2012). Dengan demikian, pertumbuhan dan perkembangan suatu wilayah merupakan suatu proses kontinyu hasil dari berbagai pengambilan keputusan di dalam maupun yang mempengaruhi suatu wilayah.

\section{Konsep Sumber Daya Perikanan}

Sumber Daya Perikanan merupakan salah sumber daya alam yang memiliki kemampuan untuk meningkatkan kesejahteraan kehidupan rakyat. Fauzi (2010) dalam bukunya, "Ekonomi Perikanan" mendefinisikan Sumber Daya Perikanan sebagai aset yang dapat bertambah ataupun berkurang, baik secara alamiah maupun dengan adanya intervensi manusia. Berdasarkan dinamika alam dan intervensi manusia ini dapat mempengaruhi secara langsung ataupun tidak langsung terhadap Sumber Daya Perikanan tersebut sepanjang waktu.

Sumber Daya Perikanan merupakan salah satu sumber daya alam yang bersifat renewable atau mempunyai sifat dapat pulih/dapat memperbaharui diri, (Fauzi, 2006). Disamping sifat renewable, menurut Widodo dan Nurhakim (2002), Sumber Daya Perikanan pada umumnya mempunyai sifat "open access" dan "common property" yang artinya pemanfaatan bersifat terbuka oleh siapa saja dan kepemilikannya bersifat umum. 
Berdasarkan pada sifat-sifat sumberdaya tersebut, maka Sumber Daya Perikanan dalam hal ini ikan bersifat unik, dan setiap orang mempunyai hak untuk memanfaatkan sumberdaya tersebut dalam batas-batas kewenangan hukum suatu Negara. Perikanan sama halnya sektor ekonomi lainnya, merupakan salah satu aktivitas yang memberikan kontribusi terhadap kesejahteraan bangsa (Fauzi, 2006). Dengan demikian Sumber Daya Perikanan dan Kelautan perlu untuk dimanfaatkan tetapi juga perlu untuk dilestarikan, sehingga pemenuhannya selalu berkelanjutan.

\section{Konsep Pembangunan Ekonomi Archipelago}

Pembangunan kelautan dan perikanan bisa dikatakan dapat memberikan masukan yang besar bagi pendapatan bangsa maupun daerah. Indonesia merupakan salah satu Negara kepulauan yang terbesar, pemanfaatan sumber daya keluatan perlu untuk ditingkatkan demi meningkatkan pembangunan ekonomi bangsa maupun daerah. Karena rendahnya pemanfaatan potensi sumberdaya kelautan yang sedemikian besar terutama disebabkan antara lain oleh; pemerintah dan masyarakat masih mengutamakan eksploitasi daratan; kualitas sumberdaya manusia yang masih rendah khususnya pada perikanan tangkap; sistem kelembagaan yang masih rendah dan lain sebagainya (Budiharsono, 2001).

Konsep pembangunan ekonomi Archipelago dilaksanakan pada wilayah kepulauan, wilayah kepulauan sebagai arena pembangunan yang merupakan wadah yang mengakomodasikan berbagai aktivitas, berbagai interaksi antara Sumber Daya Manusia (SDM) dan Sumber Daya Alam (SDA). Strategi pengembangan wilayah Archipelago yang diterapkan harus sesuai dengan sasaran pengembangan wilayah (Adisasmita, 2006).

Archipelago berarti terdiri dari pulaupulau atau keluatan, karena itu pembangunan ekonomi kepulauan lebih mempunyai konotasi dengan penjabaran konsep islands territory, sedangkan konsep pembangunan ekonomi Archipelago lebih dikaitkan dengan konsep Wawasan Nusantara, artinya pembangunan seharusnya diorientasikan kearah daratan dan kearah lautan (perairan) secara proposional. Potensi-potensi yang ada diharapkan dapat dimanfaatkan secara optimal dan berkelanjutan. Adapun yang diharapkan pembangunan di daratan dan di laut di-upayakan untuk ditingkatkan interkonekstasi-nya, respon-sitivitasnya dan resiprositasnya (Adisasmita, 2006).

Pada intinya ekonomi archipelago menganjurkan pembangunan di daratan dan pembangunan di perairan (kelautan) agar dilaksanakan secara serentak (pada saat yang sama), serempak (bersamaan), simultan (bersama-sama) dan proporsional (sesuai urgensinya dan kebutuhannya). Dengan demikian pelaksanaan daratan dan perairan (kelautan) akan berlangsug secara berkesinambungan dan secara optimal (balanced and optimal landward and seaward development) (Adisasmita, 2014).

\section{Teori Simpul Jasa Distribusi}

Dalam Teori Simpul Jasa Distribusi, Poernomosidi Hadjisaroso menekankan pentingnya peranan pusat yang selanjutnya diidentifikasikan sebagai "simpul jasa distribusi". Jasa distribusi mempunyai peranan penting dalam kehidupan pembangunan manusia secara fisik. Poernomosidi menjelaskan konsepnya bahwa perkembangan suatu wilayah ditandai oleh terjadinya pertumbuhan atau perkembangan sebagai akibat berlangsungnya berbagai kegiatan usaha, baik sektor pemerintah maupun sektor swasta yang bertujuan untuk memenuhi kebutuhan. Kegiatan usaha tersebut ditunjang oleh pertumbuhan modal serta pengembangan Sumber Daya Manusia dan Sumber Daya Alam. Jasa distribusi dengan kepadatan tinggi menunjukkan "tingkat kemudahan" yang tinggi bagi masyarakat dalam emperoleh kebutuhan untuk memenuhi hidup sehari hari ataupun untuk melaksanakan kegiatan usaha (Adisasmita, 2006).

Dengan demikian jasa distribusi itu dapat dikatakan sebagai unsur pembentuk struktur wilayah dan memberikan hasil berupa struktur pengembangan wilayah. Dengan begitu suatu wilayah dapat berkembang dan mengandalakan kekuatanyang ada dalam wilayah, sehingga potensi-potensi yang ada dalam wilayah tersebut dapat dikembangkan semaksimal mungkin. 


\section{Konsep Strategi}

Strategi merupakan suatu langka yang perlu disusun untuk mencapai sesuatu yang diinginkan, suatu wilayah atau suatu organisasi yang merencanakan berbagai kegiatan untuk meningkatkan daerah atau perusahan perlu membuat strategi yang baik sehingga tujuan tersebut dapat tercapai. Menurut Mulyadi, (2007), mendefinisikan strategi sebagai cara untuk mencapai tujuan jangka panjang. Strategi bisnis bisa berupa perluasan geografis, diversifikasi, akusisi, pengembangan produk, penetrasi pasar, rasionalisasi karyawan, divestasi, likuidasi dan joint venture.

Glueck dan Jauch mendefinisikan Strategi sebagai suatu rencana yang disatukan, luas dan berintegrasi yang menghubungkan keunggulan strategis perusahaan dengan tantangan lingkungan, yang dirancang untuk memastikan bahwa tujuan utama dari perusahaan dapat dicapai melalui pelaksanaan yang tepat oleh organisasi (Rangkuti, 2013). Hamel dan Prahald (1995), mendefinisikan strategi sebagai suatu tindakan yang bersifat incremental (senantiasa meningkat) dan terusmenerus, serta dilakukan berdasarkan sudut pandang tentang apa yang diharapkan oleh para pelanggan di masa depan. Dengan demikian, strategi hampir selalu dimulai dari apa yang dapat terjadi dan bukan dimulai dari apa yang terjadi (Rangkuti, 2013).

Menurut hemat kami, strategi merupakan suatu cara yang ditata dengan baik oleh suatu pihak (pemerintah, institusi, organisasi, perusahan maupun perorangan) dalam mencapai kesuksesan berdasarkan pada tujuan yang telah ditentukan.

\section{Analisis Strengths Weaknesses} Opportunities and Threats (SWOT)

Analisis SWOT merupakan analisis kondisi internal maupun eksternal suatu organisasi yang selanjutnya akan digunakan sebagai dasar untuk merancang strategi dan program kerja. Analisis internal meliputi penilaian terhadap faktor kekuatan (Strength) dan kelemahan (Weakness). Sementara, analisis eksternal mencakup faktor peluang (Opportunity) dan tantangan (Threat). Istilah SWOT merupakan singkatan dari empat kata, yaitu: Strength (kekuatan), Weaknesses (kelemahan), Opportunities (peluang) dan
Threat (ancaman). Keempat unsur ini merupakan aspek penting yang perlu dibahas untuk dapat mengetahui kondisi dan permasalahan yang dihadapi oleh suatu daerah atau institusi tertentu. Dengan demikian, analisis SWOT dapat pula diartikan sebagai suatu teknik analisis yang menggunakan keempat unsur tersebut sebagai variabel utama dalam melakukan analisis (Sjafrizal, 2012).

\section{Analisis Faktor Strategis Internal}

Faktor internal merupakan analisis yang dilakukan untuk dapat mengetahui pencapaian yang ingin di lakukan, sehingga tujuan dapat tercapai dengan baik dengan memperhatikan kekuatan dan kelemahan yang ada dalam suatu wilayah/organisasi tersebut. Rangkuti memaparkan kerangka tabel dengan langkahlangkahnya sebagai berikut:

a. Menentukan faktor kekuatan dan kelemahan utama pada kolom 2

b. Memberikan bobot pada masing-masing faktor pada kolom 3 dengan nilai mulai dari 1,0 (sangat penting) sampai dengan 0,0 (tidak penting) berdasarkan pada fungsi dan peranan dari faktor-faktor tersebut.

c. Menentukan skor pada kolom 4 untuk masing-masing faktor yang dimulai dari 4 (sangat baik) sampai dengan 1 (sangat baik/di bawah rata-rata),

d. Bobot pada kolom 3 dan skor pada kolom 4 dikalikan sehingga memperoleh nilai untuk masing-masing faktor dalam kolom 5 .

e. Nilai yang diperoleh pada kolom 5 dapat menunjukan tingkat strategis dari masingmasing faktor tersebut terhadap pencapaian tujuan pengembangan tersebut (Rangkuti, 2013).

\section{Analisis Faktor Strategis Eksternal}

Faktor eksternal merupakan dampak yang diciptakan dari suatu organisasi terhadap pihak luar, atau kegiatan diluar organisasi yang dapat mempengaruhi organisasi. (Tarigan, 2012). Faktor eksternal ini mempengaruhi terbentuknya opportunities and threats $(\mathrm{O}-\mathrm{T})$. Dimana faktor ini menyangkut dengan kondisikondisi yang terjadi di luar perusahan yang mempengaruhi dalam pembuatan keputusan perusahan.(Fahmi, 2013). Oleh karena itu dapat dipaparkan susunan tabel dengan langkahlangkahnya sebagai berikut:

a. Menentukan faktor-faktor kekuatan dan kelemahan utama pada kolom 2 
b. Memberikan bobot pada masing-masing faktor pada kolom 3 dengan nilai mulai dari 1,0 (sangat penting) sampai dengan 0,0 (sangat tidak penting) berdasarkan pada fungsi dan peranan dari faktor-faktor tersebut.

c. Menentukan skor pada kolom 4 untuk masing-masing faktor yang dimulai dari 4 (sangat baik) sampai dengan 1 (di bawah rata-rata), berdasarkan pengaruh faktor tersebut terhadap kondisi perusahan/ wilayah/organisasi.

d. Bobot pada kolom 3 dan skor pada kolom 4 dikalikan sehingga memperoleh nilai untuk masing-masing faktor dalam kolom 5. e. Nilai yang diperoleh pada kolom 5 dapat menunjukan tingkat strategis dari masingmasing faktor tersebut terhadap pencapaian tujuan pengembangan tersebut (Rangkuti, 2013).

Hasil perhitungan dari Tabel 1 dan 2 di atas akan kelihatan secara jelas faktor-faktor internal dan eksternal yang bersifat sangat strategis yang dapat menentukan kondisi dan daya saing dari organisasi/institusi atau wilayah yang bersangkutan. Dengan demikian akan menjadi dasar untuk dapat menyusun Matrix SWOT guna merumuskan pengembangan sesuai dengan kondisi strategis internal dan eksternal yang dimiliki.

Tabel. 1. Analisis Faktor Internal/ Internal Faktor Analisys System (IFAS)

\begin{tabular}{llccc}
\hline No. & Faktor Strategi Internal & Bobot & Skor & Nilai \\
\hline & Kekuatan (Stregths/S) & & & \\
1. & Kekuatan 1 & Bobot 1 & Skor 1 & Bobot x Skor \\
2. & Kekuatan 2 & Bobot 2 & Skor 2 & \\
3. & Kekuatan 3 & Bobot 3 & Skor 3 & \\
\hline & Jumlah & $\boldsymbol{S}_{1}$ & $\boldsymbol{S}_{2}$ & \\
\hline
\end{tabular}

\begin{tabular}{llcc} 
& Kelemahan $($ Weaknesses/W) & & \\
1. & Kelemahan 1 & Bobot 1 & Skor 1 \\
2. & Kelemahan 2 & Bobot $x$ Skor \\
3. & Kelemahan 3 & Skor 2 \\
\hline & Jumlah & Bobot 3 & Skor 3 \\
\hline & Jumlah Total & $\boldsymbol{W}_{1}$ & $\boldsymbol{W}_{2}$ \\
\hline
\end{tabular}

Sumber: Sjafrizal, 2014

Tabel. 2. Analisis Faktor Eksternal/External Faktor Analisys Summary (EFAS)

\begin{tabular}{|c|c|c|c|c|}
\hline No. & Faktor Strategi Internal & Bobot & Skor & Nilai \\
\hline & Peluang Peluang (Opportunities $/ O$ ) & & & \\
\hline 1. & Peluang 1 & Bobot 1 & Skor 1 & Bobot $x$ Skor \\
\hline \multirow[t]{2}{*}{2.} & Peluang 2 & Bobot 2 & Skor 2 & \\
\hline & Jumlah & $\mathrm{O}_{1}$ & $\mathrm{O}_{2}$ & \\
\hline
\end{tabular}

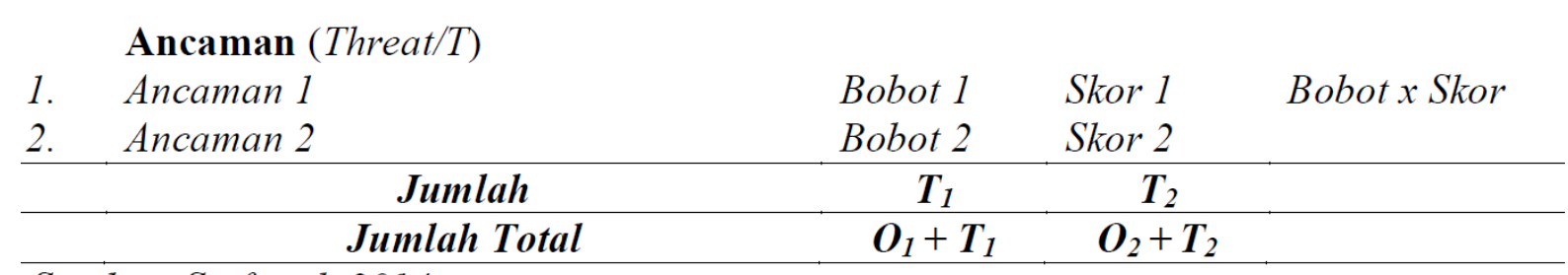

Sumber: Sjafrizal, 2014 


\section{Matriks Internal-Eksternal (IE Matriks)}

Matriks Internal Eksternal (IE matriks) dapat didentifikasikan 9 sel strategi perusahaan, tetapi pada prinsipnya kesembilan sel itu dapat dikelompokkan menjadi tiga strategi utama, yaitu:

1. Growth strategy yang merupakan pertumbuhan perusahaan itu sendiri (sel 1, 2, dan 5) atau upaya diversifikasi (sel 7 dan 8).

2. Stability strategy adalah strategi yang diterapkan tanpa mengubah arah strategi yang telah ditetapkan.

3. Retrenchment strategy (sel 3, 6, dan 9) adalah usaha memperkecil mengurangi usaha yang dilakukan perusahaan, (Rangkuti, 2013).

\section{Matriks SPACE}

Matriks SPACE merupakan dasar untuk mengetahui posisi strategis yang didapat dari nilai rating yang dimiliki oleh faktorfaktor strateginya (Gambar 1). Matriks SPACE digunakan untuk melihat garis vektor positif dan negatif untuk internal dan eksternal, (Rangkuti, 2013).

Kuadran I (positif, positif); Posisi ini menandakan sebuah wilayah yang kuat dan berpeluang, Rekomendasi strategi yang diberikan adalah Progresif.

Kuadran II (positif, negatif); Posisi ini menandakan sebuah wilayah yang kuat namun menghadapi tantangan yang besar.

Rekomendasi strategi yang diberikan adalah Diversifikasi Strategi.

Kuadran III (negatif, positif); Posisi ini menandakan sebuah wilayah yang lemah namun sangat berpeluang. Rekomendasi strategi yang diberikan adalah Ubah Strategi,

Kuadran IV (negatif, negatif) Posisi ini menandakan sebuah wilayah yang lemah dan menghadapi tantangan besar. Rekomendasi strategi yang diberikan adalah Strategi Bertahan, (Rangkuti, 2013).

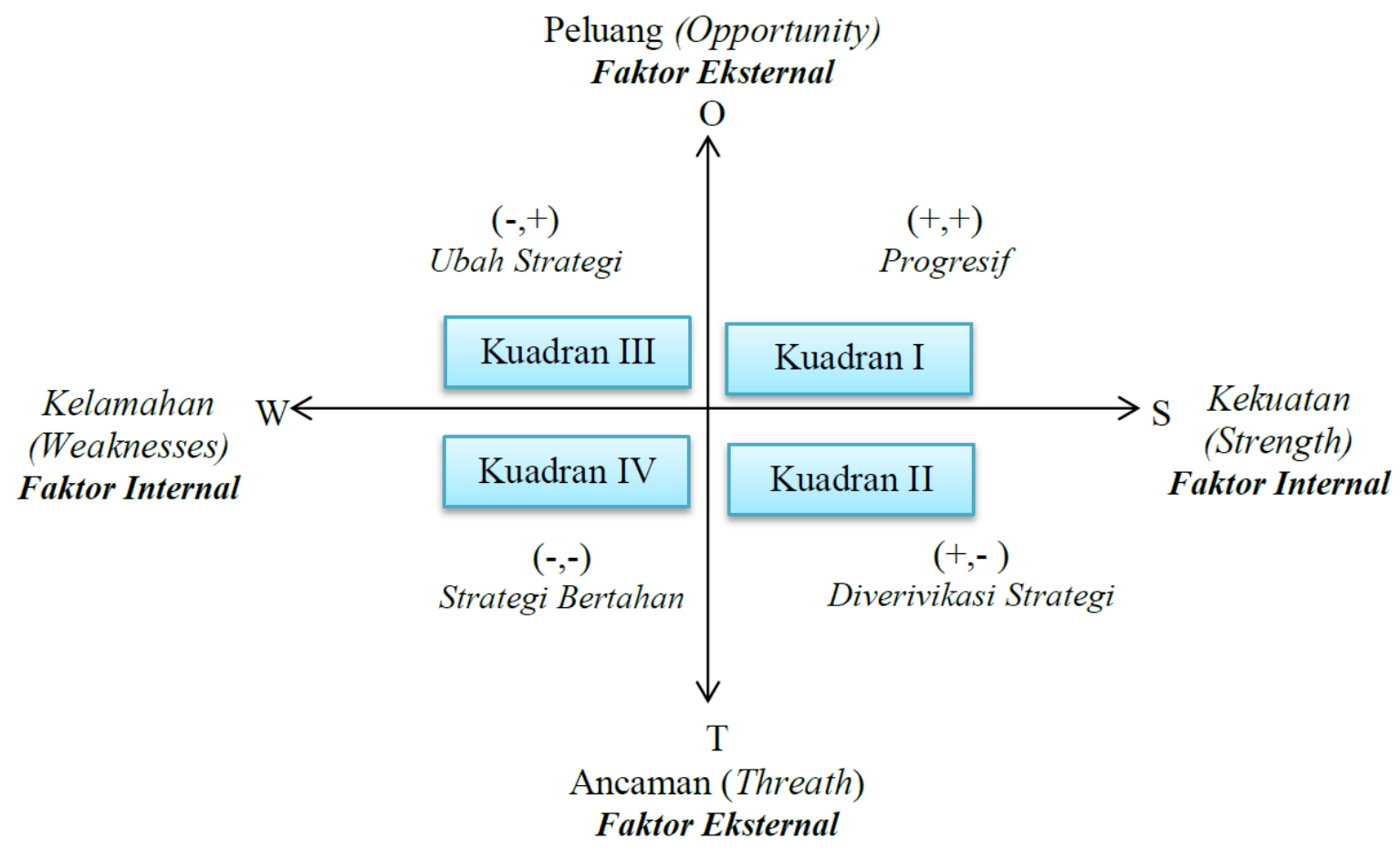

Gambar. 1. Matriks SPACE 


\begin{tabular}{|c|c|c|}
\hline $7^{\text {IFAS }}$ & $\begin{array}{c}\text { Kekuatan } \\
\text { (Streagths/S) } \\
\text { Strategi } S-O\end{array}$ & $\begin{array}{c}\text { Kelemahan } \\
\text { (Weaknesses/W) } \\
\text { Strategi } \boldsymbol{W}-\boldsymbol{O}\end{array}$ \\
\hline $\begin{array}{c}\text { Peluang } \\
\text { (Opportunities/O) }\end{array}$ & $\begin{array}{l}\text { Strategi yang menggunakan kekuatan } \\
\text { dengan memanfaatkan peluang yang ada. }\end{array}$ & $\begin{array}{l}\text { Strategi yang memperkecil kelemahan yang } \\
\text { ada dengan memanfaatkan }\end{array}$ \\
\hline Ancaman (Threats/T) & $\begin{array}{l}\text { Strategi } \boldsymbol{S} \text { - } \boldsymbol{T} \\
\text { Strategi yang menggunakan kekuatan untuk } \\
\text { mengatasi ancaman yang ada }\end{array}$ & \begin{tabular}{l}
\multicolumn{3}{c}{ Strategi $\mathbf{W}-\boldsymbol{O}$} \\
Strategi yang memperkecil kelemahan \\
dengan menghindari ancaman
\end{tabular} \\
\hline
\end{tabular}

Sumber: Sjafrizal, 2014

Gambar 2. Matriks SWOT

\section{Matriks SWOT}

Matriks SWOT adalah matriks yang menginteraksikan faktor strategis internal dan eksternal (Gambar 2). Matrik ini dapat menggambarkan secara jelas bagaimana peluang dan ancaman (eksternal) yang dihadapi dapat disesuaikan dengan kekuatan dan kelemahan (internal) yang dimiliki (Rangkuti, 2013). Hasil dari interaksi faktor strategis internal dengan eksternal menghasilkan alternatif-alternatif strategi. Model Matrik Analisis SWOT dapat dilihat pada Gambar 2.

Dari gambar Matriks SWOT di atas, dapat dijelaskan langkah-langkah sebagai berikut:

a. Strategi S - O : Strategi ini dibuat berdasarkan jalan pikiran memanfaatkan seluruh kekuatan untuk merebut dan memanfaatkan peluang sebesar-besarnya.

b. Strategi $S-T$ : Strategi ini adalah strategi dalam menggunakan kekuatan yang dimiliki untuk mengatasi ancaman.

c. Strategi W - O : Strategi ini diterapkan berdasarkan pemanfaatan peluang yang ada dengan cara meminimalkan kelemahan yang ada.

d. Strategi $\mathrm{W}-\mathrm{T}$ : Strategi ini didasarkan pada kegiatan usaha meminimalkan kelemahan yang ada serta menghindari ancaman (Sjafrizal, 2014).

\section{Kerangka Pemikiran Teoritis}

Bidang kelautan dan perikanan merupakan bidang yang sangat menjanjikan dalam pembangunan nasional masa depan, namun wilayah-wilayah kepulauan, kelautan dan sebagainya pada umumnya merupakan wilayah yang kurang maju atau lamban dalam perkembangannya (Adisasmita, 2014). Penyusunan strategi dalam pengembangan pada subsektor perikanan di Kabupaten Maluku Tenggara Barat diawali dengan mengidentifikasi berbagai faktor baik yang bersifat internal maupun eksternal dari dinasdinas terkait yang ada di kabupaten Maluku Tenggara Barat, dan lebih khusus dinas Kelautan dan Perikanan kabupaten Maluku Tenggara Barat.

Dari faktor-faktor internal dan eksternal, maka akan dibentuk suatu strategi dengan menggunakan matriks SWOT. Yang mana secara diagram dapat dijelaskan secara menyeluruh kerangka pemikiran konseptual dalam perumusan strategi pengembangan perikanan tangkap di kabupaten Maluku Tenggara Barat pada Gambar 3.

\section{Rumusan Masalah}

Berdasarkan latar belakang masalah, maka dapat dikatakan bahwa peningkatan pengembangan perikanan tangkap dan budidaya perlu untuk dikembangan dengan strategi yang lebih baik. Dengan demikian yang menjadi Permasalahan Utama dalam penelitian ini, yaitu bagaimana Strategi Alternatif yang Baik dalam peningkatan Perikanan Tangkap dan Perikanan Budidaya di Kabupaten Maluku Tenggara Barat, sehingga dapat memberikan nilai tambah yang signifikan bagi masyarakat maupun daerah. 


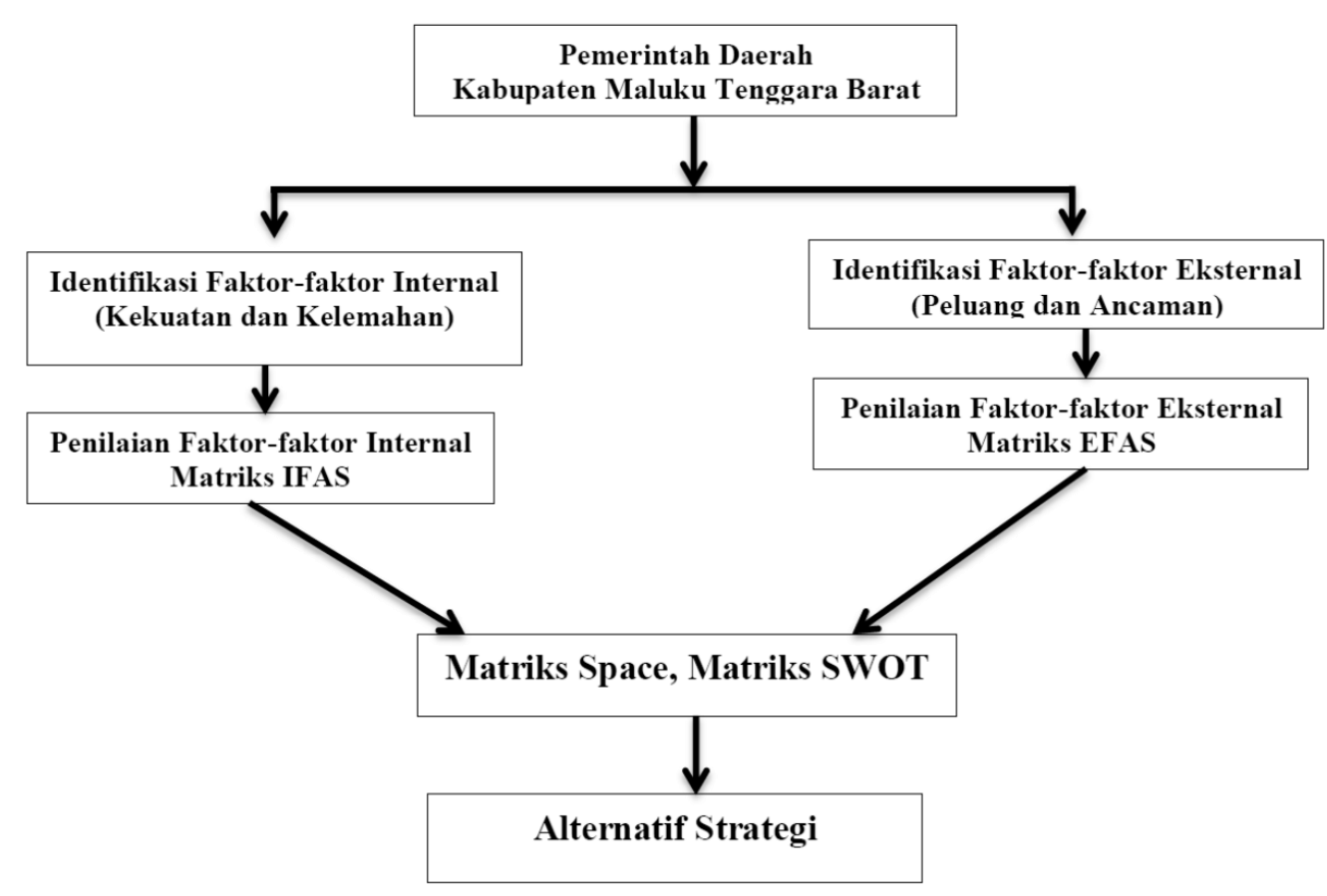

Gambar. 3. Kerangka pemikiran konseptual strategi Pengembangan Perikanan Tangkap

\section{Tujuan Penelitian}

Tujuan dilaksanakannya penelitian adalah: Menganalisis strategi yang baik dalam pengembangan Sumber Daya Perikanan yang di Kabupaten Maluku Tenggara Barat, sehingga dapat memberikan pendapatan yang layak bagi masyarakat dan daerah.

\section{Manfaat Penelitian}

Hasil dari penelitian ini diharapkan dapat menjadi masukkan bagi pengembangan Subsektor Perikanan di Kabupaten Maluku Tenggara Barat dan untuk semua pemangku kebijakan pada umumnya dan terutama Pemerintah Daerah Kabupaten Maluku Tenggara Barat pada khususnya. Selain itu, penelitian ini bisa digunakan sebagai dasar penelitian lanjutan yang berkaitan dengan Pengembangan Subsektor Perikanan di Kabupaten Maluku Tenggara Barat.

\section{METODOLOGI PENELITIAN}

\section{Tempat dan Waktu Penelitian}

Penelitian ini dilakukan pada wilayah Kabupaten Maluku Tenggara Barat, Propinsi
Maluku. Penelitian ini dimulai pada bulan April-November 2015.

\section{Metode Pengumpulan Data}

Data yang digunakan dalam penelitian adalah data primer dan data sekunder. Data primer diperoleh dengan cara menyebarkan kuesioner kepada responden dengan jumlah responden sebanyak 10. Data Sekunder berupa data yang sudah dipublikasikan oleh berbagai instansi pemerintah, antara lain peta, buku pedoman, laporan instansi, tulisan ilmiah.

\section{Definisi Operasional Variabel}

Dalam penulisan ini, perlu adanya kesamaan pemahaman terhadap variabel yang akan diteliti dalam penelitian strategi pengembangan pada subsektor perikanan, maka perlu adanya definisi operasional variabel. Variabel yang digunakan dalam analisis SWOT terdiri dari Kekuatan (Strengths), Kelemahan (Weaknesses), Peluang (Opportunities), dan Ancaman (Threats) adalah sebagai berikut: 


\section{Faktor Internal :}

\section{Kekuatan (Strengths)}

a. Potensi sumber daya alam, yakni luas laut yang dapat mendukung pengembangan sub sektor perikanan yang ada.

b. Ketersediaan tenaga kerja yang kompeten dalam bidang perikanan.

c. Potensi Laut untuk pengembangan Usaha dalam subsektor Perikanan.

d. Meningkatkan pengolahan sumber daya alam pada subsektor perikanan

e. Kebijakan Pemerintah, mengenai pengembangan subsektor perikanan.

\section{Kelemahan (Weaknesses)}

a. Kualitas sumber daya manusia yang relatif masih rendah,

b. Kurang adanya pemahaman yang baik tentang teknologi,

c. Ketersedian sarana dan prasarana.

d. Kurang adanya penyuluhan dari para petugas lapangan.

e. Kurangnya dukungan dari lembaga informal mapun formal

\section{Faktor Eksternal :}

\section{Peluang (Opportunities)}

a. Otonomi Daerah:

b. Kebijakan nasional untuk pengembangan kegiatan bisnis kelautan dan juga adanya rencana pengembangan rumput laut.

c. Dukungan pemerintah pusat, propinsi maupun daerah,

d. Potensi pasar, komoditi ikan dari bebagai jenis yang dihasilkan dari penangkapan maupun budidaya memiliki pasar eksport.

\section{Ancaman (Threats)}

a. Kondisi alam;

b. Sosial budaya masyarakat;

c. Pencurian ikan

d. Terbatasnya pasokan energy

e. Harga produk yang tidak stabil;

\section{Analisis Data}

Analisis data yang dilakukan dalam penelitian ini didahului dengan mengumpulkan data dari instansi terkait dan lewat kuesioner yang disebarkan kepada responden, kemudian dilakukan tabulasi data untuk menjawab permasalahan. Selanjutnya dilakukan dengan analysis SWOT (Strengths, Weaknesses, Opportunities, Threats). Mengidentifikasi faktor internal dan faktor eksternal, yang disusun dalam matriks IFAS (Internal Faktor Analisys System) dan EFAS (External Faktor Analisys Summary), lalu disusun dalam matriks SPACE. Kemudian dianalisis dengan SWOT sehingga dapat menggambarkan secara jelas kekuatan (Strengths) dengan memanfaatkan peluang (Opportunities), kekuatan (Strengths) untuk menghilangkan ancaman (Threats), mengurangi kelemahan (Weaknesses) untuk memperoleh peluang (Opportunities), dan cara mengatasi kelemahan untuk menghilangkan ancaman (Threats).

\section{Model Analisis Data}

Dalam penelitian ini, metode yang digunakan oleh penulis yaitu: Analisis SWOT. Dalam analisis SWOT ditentukan nilai pada bobot (Tabel 3) dan skor (Tabel 4) berdasarkan pada hasil analisis data yang diperoleh dari responden. Dimana Bobot yang ditentukan berdasarkan penting atau tidak pentingnya suatu variabel, sedangkan Rating yang diberikan berdasarkan pada baik atau tidaknya suatu variabel 
Tabel. 3. Rumus Pembobotan

\begin{tabular}{cccc}
\hline & (Kekuatan dan Peluang) & Bobot & (Kelemahan dan Ancaman) \\
\hline \multirow{2}{*}{ Sangat penting } & $\mathbf{1 , 0 0}$ & Sangat penting \\
Pategori & Standart & $\mathbf{0 , 7 5}$ & Penting \\
& Tidak penting & $\mathbf{0 , 5 0}$ & Standart \\
& Sangat tidak penting & $\mathbf{0 , 2 5}$ & Tidak penting \\
& & $\mathbf{0 , 1 0}$ & Sangat tidak penting
\end{tabular}

Tabel.4. Rumus Peratingan

\begin{tabular}{cccc}
\hline & Rating & (Kelemahan dan Ancaman) \\
\hline Sangat Baik & 4 & Sangat Baik \\
Kategori & Di atas rata-rata & 3 & Di atas rata-rata \\
& Rata-rata & 2 & Rata-rata \\
& Di bawah rata-rata & 1 & Di bawah rata-rata \\
\hline
\end{tabular}

Sumber: Rangkuti, 2013

Untuk Nilai dihitung dengan menggunakan formula sebagai berikut:

$\mathrm{NILAI}=\mathrm{BOBOT} \times \mathrm{SKOR}$

Nilai skor diperoleh berdasarkan hasil nilai bobot dikali nilai rating. Total nilai skor untuk faktor internal menunjukan bahwa semakin nilainya mendekati 1 , semakin banyak kelemahan internal dibandingkan kekuatannya. Sedangkan semakin nilainya mendekati 4 , semakin banyak kekuatannya dibandingkan kelemahannya. Begitu juga dengan total nilai skor untuk faktor eksternal. Semakin total nilai skor mendekati 1 , semakin banyak ancamannya dibandingkan peluang. Sedangkan apabila total nilai skor mendekati 4 , artinya semakin banyak peluang dibandingkan ancaman.

\section{HASIL DAN PEMBAHASAN}

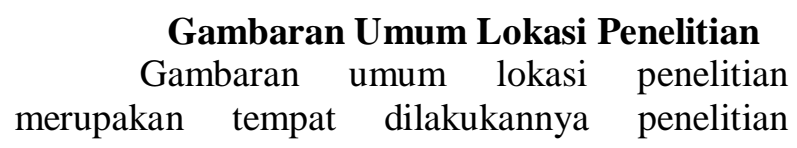

dimana lokasi penelitian bertempat di Kabupaten Maluku Tenggara Barat. Gambaran umum lokasi penelitian yang dijelaskan pada bagian ini meliputi keadaan geografis dan kondisi sosial kependudukan di Kabupaten Maluku Tenggara Barat.

\section{Keadaan Geografis}

Kabupaten Maluku Tenggara Barat merupakan salah satu kabupaten yang berada di Propinsi Maluku yang terletak pada bagian Tenggara Propinsi Maluku. Kabupaten Maluku Tenggara Barat dibentuk berdasarkan UndangUndang Nomor 6 Tahun 2000 tentang Perubahan Undang-Undang Nomor 46 Tahun 1999 tentang Pembentukan Propinsi Maluku Utara, Kabupaten Buru, dan Kabupaten Maluku Tenggara Barat. Kabupaten Maluku Tenggara Barat secara astronomi terletak antara $6^{0} 34^{\prime} 24^{\prime \prime}-8^{0} 24^{\prime} 36^{\prime \prime}$ 
Lintang Selatan dan $130^{\circ} 37^{\prime} 47^{\prime \prime}-133^{\circ} 4^{\prime} 12^{\prime \prime}$ Bujur Timur.

Adapun letaknya menurut Geografi dibatasi antara lain oleh:

- Sebelah Utara: Laut Banda

- Sebelah Selatan: Laut Timor dan Samudera Pasifik

- Sebelah Barat: Gugus Pulau Babar Sermatang

- Sebelah Timur: Laut Arafura

Kabupaten Maluku Tenggara Barat merupakan daerah kepulauan dan terkonsentrasi pada Gugus Pulau Tanimbar yang mempunyai luas keseluruhan 52.995,20 $\mathrm{km}^{2}$ yang terbagi dalam 10 kecamatan (Sumber: BPS Kabupaten Maluku Tenggara Barat, 2014)

Kabupaten Maluku Tenggara Barat merupakan daerah yang wilayah kepulauannya sangat luas bila dibandingkan dengan wilayah daratan, seperti yang, wilayah daratan seluas $10.102,92 \mathrm{~km}^{2} \quad(19,06 \%)$, sedangkan wilayah perairan seluas $\pm 42.892,28 \mathrm{~km}^{2} \quad(80,94 \%)$. Kecamatan yang mempunyai wilayah daratan yang paling luas yaitu kecamatan Wermaktian, dengan luas daratan sebesar $2941,16 \mathrm{~km}^{2}$ atau sebesar $29,11 \%$, dan memiliki luas laut $29.11 \mathrm{~km}^{2}$ atau $29,11 \%$. Sedangkan wilayah yang memiliki luas laut dan daratan yang paling kecil yaitu kecamatan Yaru, dengan luas daratan sebesar $79,42 \mathrm{~km}^{2}$ atau $0,79 \%$ dan luas laut $337,2 \mathrm{~km}^{2}$.

\section{Kondisi Sosial Kependudukan}

Kondisi kependudukan merupakan suatu kondisi yang berhubungan dengan perubahan keadaan penduduk yang dapat berpengaruh dan dipengaruhi oleh keberhasilan pembangunan berkelanjutan.

a. Jumlah dan Sebaran Penduduk

Jumlah penduduk di Kabupaten Maluku

Tanggara Barat berdasarkan data tahun 2014 sebesar 108.665 jiwa dengan kepadatan penduduk rata-rata $165 \mathrm{jiwa} / \mathrm{km} 2$. Jumlah penduduk tertinggi terdapat di Kecamatan Tanimbar Selatan sebanyak 32.567 jiwa atau $29,97 \%$ dengan kepadatan $39 \mathrm{jiwa} / \mathrm{km}^{2}$. Hal ini dikarenakan Kecamatan Tanimbar Selatan merupakan ibukota Kabupaten Maluku Tenggara Barat dan hampir seluruh aktivitas perekonomian berada disana. Kepadatan penduduk di Kabupaten Maluku Tenggara Barat dapat dilihat pada tabel berikut:

\section{b. Struktur Penduduk Menurut Mata} Pencaharian
Sektor lapangan kerja di Maluku Tenggara Barat tahun 2014 sebanyak 7 (tujuh) sektor dengan jumlah tenaga kerja sebanyak 1.431 jiwa. Dimana jumlah tenaga kerja tertinggi berada di sektor perdagangan besar, eceran, rumah makan dan hotel sebanyak 232 jiwa, sedangkan terendah berada di sektor keuangan dan sejenisnya sebanyak 36 jiwa.

\section{Kondisi Sumber Daya Kelautan dan Perikanan}

Sumber daya kelautan dan perikanan merupakan salah satu aktivitas yang memberikan kontribusi terhadap suatu wilayah maupun bangsa. Seperti juga yang diungkapkan Fauzi, bahwa perikanan dapat memberikan kontribusi yang cukup tinggi terhadap pendapatan Negara (Fauzi, 2006). Kondisi sumber daya perikanan di Kabupaten Maluku Tenggara Barat sangat menjanjikan dalam kesejahteraan masyarakat. Dengan demikian, pada bagian ini akan dipaparkan beberapa Sumber Daya Perikanan yang ada di Kabupaten Maluku Tenggara Barat, antara lain jumlah produksi perikanan tangkap dan pembudidayaan rumput laut.

1. Rumah Tangga Perikanan dan Nelayan

Jumlah rumah tangga perikanan dan nelayan di Kabupaten Maluku Tenggara Barat pada tahun 2014 sebanyak 2.876 rumah tangga dan jumlah nelayan pada tahun 2014 sebanyak 9.378 dengan jumlah tertinggi berada di Kecamatan Tanimbar Selatan sebanyak 561 rumah tangga nelayan atau sebesar $19,5 \%$ dan 1.746 nelayan atau sebesar 18,6\%, (Dinas Kelautan dan Perikanan Kabupaten Maluku Tenggara Barat)

\section{Jumlah Produksi Perikanan}

Produksi perikanan merupakan salah satu kekayaan laut yang dimiliki oleh suatu wilayah. Wilayah Maluku Tenggara Barat ini sebagian besar berupa samudera yang didalamnya terdapat berbagai ragam jenis ikan dan kekayaan alam lainnya dengan potensi perikanan, mempunyai jumlah produksi yang cukup memadai, seperti tuna, cakalang, tongkol, marlin, tengiri dengan sentra penghasil ikan di wilayah ini pada tahun 2014 adalah di Kecamatan Tanimbar Selatan sebesar 1.474,92 ton atau $17,21 \%$ dan Tanimbar Utara sebesar $1.382,76$ ton atau $16,13 \%$, (Dinas Kelautan dan 
Perikanan 2014 dan BPS; Maluku Tenggara Barat dalam Angka, 2014)

Potensi Perikanan Tangkap di laut Kabupaten Maluku Tenggara Barat sangat menjanjikan dalam meningkatkan pendapatan masyarakat dan daerah. Dengan jumlah produksi terbanyak terdapat di Kecamatan Tanimbar Selatan dengan produksi sebagai 1 474,92 ton atau $17,21 \%$ dengan nilai sebesar 19,38 miliar rupiah atau $17.40 \%$. dengan demikian potensi sumber daya kelautan sangat menjanjikan dalam meningkatkan kehidupan masyarakat yang lebih layak.

\section{Kegiatan Budidaya Rumput Laut}

Kegiatan budidaya rumput laut merupakan salah satu kegiatan yang sering dilakukan masyarakat di pesisir pantai pulau Yamdena. Kegiatan ini dilakukan karena potensi sumber daya rumput laut sangat baik untuk dimanfaatkan demi kebutuhan kehidupan rumah tangga. Pengembangan kelautan dan perikanan di Kabupaten Maluku Tenggara Barat merupakan suatu hal yang sangat baik karena mempunyai potensi yang sangat menjanjikan. Salah satu komoditas yang potensial untuk dikembangkan di Kabupaten Maluku Tenggara Barat adalah rumput laut.

Luas lahan wilayah Lautan Maluku Tenggara Barat yang digunakan untuk budidaya rumput laut sebesar 176.107 ha, petani rumput laut dapat mempergunakan lahan untuk memanfaatkan pembudidayaan rumput laut. Sumber Daya Kelautan Rumput Laut sangat potensial untuk dikembangkan di wilayah Kabupaten Maluku Tenggara Barat. Hasil produksi budidaya rumput laut basah di Kabupaten Maluku Tenggara Barat tahun 2014 mencapai 20,637,593 ton dengan nilai sebesar Rp. 103,187,965,000,- Sedangkan untuk produk rumput laut kering mencapai 2,579,629 ton dengan nilai sebesar Rp. 23,216,656,500,-. Dengan adanya potensi dan kekayaan laut yang bagitu baik, namun terdapat pula beberapa permasalahan yang dihadapi terkait belum optimalnya kegiatan budidaya rumput laut adalah lemahnya Sumber Daya Manusia dan kelembagaan serta harga rumput laut di pasaran yang kadang tidak menentu.

\section{Analisis SWOT}

Analisis SWOT merupakan suatu analisis untuk dapat mengetahui kondisi internal maupun eksternal dari daerah atau wilayah yang selanjutnya akan digunakan sebagai dasar untuk merancang strategi dan program kerja. Kondisi internal dapat mengetahui kekuatan yang ada untuk dapat dimaksimalkan dalam mencapai tujuan, dan juga kelemahan sehingga dapat diminimalisir, sedangkan kondisi eksternal untuk melihat peluang-peluang yang ada serta ancaman yang muncul. Pada bagian ini akan dijelaskan tentang kondisi internal dan eksternal dari wilayah Kabupaten Maluku Tenggara Barat.

\section{Faktor Internal}

Faktor internal merupakan faktorfaktor dari dalam wilayah yang strategis untuk dikembangan atau dihilangkan berdasarkan pada hasil identifikasi. Faktor internal ini terdiri dari kekuatan dan kelemahan yang terdapat di dalam wilayah.

\section{Kekuatan (Strengths)}

a. Potensi sumber daya alam; berdasarkan pada luas laut dan perairan, maka Kabupaten Maluku Tenggara, memiliki laut yang sangat luas sehingga memiliki kekayaaan dan keanekaragaman sumberdaya ikan dan non ikan yang potensial untuk dikembangkan

b. Ketersediaan tenaga kerja yang handal; pada subsektor Perikanan dapat memberikan lapangan kerja yang tidak kecil.

c. Potensi Laut; Kabupaten Maluku Tenggara Barat memiliki luas laut yang sangat besar bila dibandingkan dengan luas darat. Total luas laut Kabupaten Maluku Tenggara Barat sebesar $42.892 .27 \mathrm{~km}^{2}(80,94 \%)$.

d. Meningkatkan pengolahan sumber daya alam; pengolahan sumber daya alam yang berkualitas. Dengan adanya pengolahan yang baik dan berkualitas akan dapat mempengaruhi nilai jual di pasar ekspor.

e. Kebijakan Pemerintah; Dengan adanya penetapan Maluku sebagai "Lumbung Ikan Nasional", maka adanya kebijakan pemerintah daerah dalam meningkatkan 
pengolahan perikanan tangkap dan budidaya rumput laut di Kabupaten Maluku Tenggara Barat.

\section{Kelemahan (Weaknesses)}

a. Kualitas sumber daya manusia yang relatif masih rendah; sumber daya manusia merupakan suatu hal yang sangat penting dalam pengembangan pada subsektor perikanan.

b. Kurang adanya penyuluhan dari para petugas lapangan; Banyak kelompok Usaha yang telah dibentuk oleh dinas yang terkaitan namun dalam tindaklanjutnya kurang adanya perhatian yang baik.

c. Ketersedian sarana dan prasarana; ketersediaan sarana dan prasarana belum cukup memadai.

d. Kurang adanya pemahaman yang baik tentang teknologi; Banyak para pelaku usaha dibidang perikanan yang masih sangat rendah kemampuanya terhadap teknologi, dengan demikian perlu untuk ditingkatkan dalam meningkatkan pengolahan dan produksi perikanan.

e. Kurang dukungan dari lembaga informal mapun formal; Pemerintah perlu bekerja sama dan memberikan kesempatan kepada pihak swasta untuk dapat bersama-sama meningkatkan dan mengolah sumberdaya alam keluatan yang ada di Kabupaten Maluku Tenggara Barat.

\section{Faktor Eksternal}

Faktor eksternal ini terdiri dari peluang dan ancaman yang akan dihadapi dalam pengembangan.

\section{Peluang (Opportunities)}

a. Otonomi Daerah; Dengan adanya Otonomi daerah, maka daerah diberikan kuasa untuk mengatur dan mengolah sumber daya alam sendiri.

b. Kebijakan Nasional untuk kelautan;

c. Dukungan pemerintah pusat, propinsi maupun daerah: Pembangunan perikanan yang berkelanjutan membutuhkan dukungan dari segenap stakeholder, baik dari pemerintah, pelaku usaha, akademisi maupun masyarakat luas.

d. Potensi pasar; Kabupaten Maluku Tenggara Barat merupakan daerah perbatasan, dengan begitu akses pasar semakin terbuka dalam mendistribusikan kekayaan kelautan ke kota-kota yang dapat terjangkau seperti Kupang dan Surabaya.

\section{Ancaman (Threats)}

a. Kondisi alam; Kondisi alam yang tidak menentu akan menghambat proses pemasaran ke luar kota Saumlaki.

b. Sosial budaya masyarakat; masyarakat masih menganggap hak kepemilikan mereka.

c. Pencurian ikan (Illegal Fishing);

d. Terbatasnya pasokan energy; dengan keterbatasan ini, maka para nelayan akan tidak dapat melaksanakan aktivitas mereka.

e. Harga produk yang tidak stabil; perlu adanya peningkatan nilai sumber daya keluatan.

\section{Analisis Faktor Internal dan Eksternal}

Analisis Eksternal Internal merupakan analisis yang digunakan untuk memahami kondisi internal (kekuatan dan kelemahan) dan situasi eksternal (peluang dan hambatan).

\section{a. Analisis Faktor Internal}

Dalam analisis ini diberikan bobot dan skor total berdasarkan pada hasil analisis dari faktor internal dengan penghitungan hasil kuesioner, seperti yang terlihat pada Tabel 5.

Tabel. 5 menunjukan bahwa jumlah skor untuk kekuatan adalah 1.484, sedangkan jumlah skor pada kelemahan adalah 1.214 , nilai untuk skor total rata diperoleh dari hasil penambahan antara skor untuk kekuatan dan skor dari kelemahan, sehingga memperoleh nilai 2.698. Maka total skornya untuk faktor internalnya adalah 2.698, dengan demikian, hasil ini dapat menjadi dasar dalam menganalisis faktor internal dengan mengandalkan kekuatan untuk melihat kelemahan-kelemahan. 


\section{b. Analisis Faktor Eksternal}

alam analisis eksternal dapat diindentifikasi peluang dan ancaman yang ada yang perlu untuk di perhatikan, sehingga dapat menjadi patokan dalam pengembangan selanjutnya. Bobot dan skor total diberikan berdasarkan pada hasil analisis dari faktor eksternal dengan penghitungan hasil kuesioner.

Tabel 6 menunjukkan bahwa angkaangka pada bobot dan skor tampak secara jelas faktor-faktor eksternal. Skor untuk Peluang adalah 1.254, sedangkan skor pada Ancaman adalah 1.148, nilai untuk skor total rata-rata diperoleh dari hasil penambahan antara skor untuk kekuatan dan skor dari kelemahan, sehingga memperoleh nilai 2.401 .

\section{a. Matriks Internal Eksternal}

Berdasarkan pada hasil Analisis faktor internal dan eksternal maka nilai IFAS yang didapat adalah 2.698 sedangkan nilai total EFAS adalah 2.401, hasil analisisnya dapat dilihat pada gambar berikut:

Tabel 5. Evaluasi Faktor Internal

\begin{tabular}{|c|c|c|c|}
\hline Faktor Internal & Bobot & Rata-rata & $\begin{array}{l}\text { Skor Total } \\
\text { Rata-rata }\end{array}$ \\
\hline \multicolumn{4}{|l|}{ Kekuatan (Strengths) } \\
\hline 1. Potensi sumber daya alam & 0.119 & 3.90 & 0.462 \\
\hline 2. Ketersedian tenaga kerja yang handal & 0.102 & 2.50 & 0.254 \\
\hline 3. Potensi Laut & 0.094 & 2.70 & 0.254 \\
\hline 4. Meningkatkan pengolahan sumber daya alam & 0.093 & 2.00 & 0.186 \\
\hline \multirow[t]{2}{*}{ 5. Kebijakan Pemerintah, } & 0.104 & 3.20 & 0.331 \\
\hline & 0.511 & & 1.484 \\
\hline \multicolumn{4}{|l|}{ Kelemahan (Weaknesses) } \\
\hline 1. Kualitas sumber daya manusia yang relatif masih rendah & 0.101 & 2.30 & 0.233 \\
\hline 2. Kurang adanya penyuluhan dari para petugas lapangan & 0.096 & 2.20 & 0.212 \\
\hline 3. Ketersedian sarana dan prasarana & 0.095 & 1.80 & 0.171 \\
\hline 4. Kurang adanya pemahaman yang baik tentang teknologi & 0.097 & 2.90 & 0.280 \\
\hline $\begin{array}{l}\text { Masih kurangnya dukungan dari lembaga informal maupun } \\
\text { formal }\end{array}$ & 0.100 & 2.60 & 0.260 \\
\hline
\end{tabular}

Sumber:Data Primer dikumpulkan dan diolah, 2015

0.489

1.214

Tabel. 6. Evaluasi Faktor Eksternal

\begin{tabular}{lrrr}
\multicolumn{1}{c}{ Faktor Eksternal } & Bobot & Rata-rata & $\begin{array}{c}\text { Skor Total } \\
\text { Rata-rata }\end{array}$ \\
\hline $\begin{array}{l}\text { Peluang (Opportunities) } \\
\text { 1. Otonomi Daerah }\end{array}$ & 0.115 & 2.90 & 0.334 \\
2. Kebijakan nasional & 0.108 & 3.00 & 0.324 \\
3. Dukungan pemerintah pusat, propinsi & & & 0.318 \\
daerah & 0.114 & 2.80 & 0.278 \\
4. Potensi pasar & 0.116 & 2.40 & $\mathbf{1 . 2 5 3}$ \\
\hline & $\mathbf{0 . 4 5 2}$ & & 0.322 \\
Ancaman (Threats) & & & 0.225 \\
\hline 1. Kondisi alam & 0.107 & 3.00 & 0.196 \\
2. Sosial budaya masyarakat & 0.112 & 2.00 & 0.159 \\
3. Pencurian ikan & 0.115 & 1.70 & 0.247 \\
4. Terbatasnya pasokan energy & 0.106 & 1.50 & $\mathbf{1 . 1 4 8}$ \\
5. Harga produk yang tidak stabil & 0.107 & 2.30 & \\
\hline
\end{tabular}

Sumber:Data Primer dikumpulkan dan diolah, 2015 


\begin{tabular}{|c|c|c|c|}
\hline Internal & Kuat & Rata-rata & Lemah \\
\hline \multirow[t]{2}{*}{$\begin{array}{c}\text { Tinggi } \\
(3.00-4.00)\end{array}$} & $\begin{array}{c}\text { I } \\
\text { Pertumbuhan }\end{array}$ & $\begin{array}{c}\text { II } \\
\text { Pertumbuhan }\end{array}$ & $\begin{array}{c}\text { III } \\
\text { Penciutan }\end{array}$ \\
\hline & $\begin{array}{l}\text { Strategi konsentrasi } \\
\text { melalui integrasi } \\
\text { vertikal }\end{array}$ & $\begin{array}{c}\text { Strategi konsentrasi melalui } \\
\text { integrasi horisontal }\end{array}$ & Strategi turnaround \\
\hline $\begin{array}{c}\text { Sedang } \\
(2.00-2.99)\end{array}$ & $\begin{array}{c}\text { IV } \\
\text { Stabilitas } \\
\text { Strategi stabilitas }\end{array}$ & $\begin{array}{c}\mathrm{V} \\
\text { Pertumbuhan } \\
\text { Stabilias } \\
\text { Strategi konsentrasi melalui } \\
\text { integrasi horizontal atau } \\
\text { stabilitas }\end{array}$ & $\begin{array}{c}\text { VI } \\
\text { Penciutan } \\
\text { Strategi divestasi }\end{array}$ \\
\hline $\begin{array}{c}\text { Rendah } \\
(1.00-1.99)\end{array}$ & $\begin{array}{c}\text { VII } \\
\text { Pertumbuhan } \\
\text { Strategi diversikasi } \\
\text { konsentrik }\end{array}$ & $\begin{array}{c}\text { VIII } \\
\text { Pertumbuhan } \\
\text { Strategi diversikasi } \\
\text { konglomerat }\end{array}$ & $\begin{array}{c}\text { IX } \\
\text { Likuidasi } \\
\begin{array}{c}\text { Strategi likuidasi atau } \\
\text { bangkrut }\end{array}\end{array}$ \\
\hline
\end{tabular}

Gambar. 4 Analisis Matriks Internal Eksternal

Pada Gambar 4 terlihat bahwa posisi subsektor perikanan di Kabupaten Maluku Tenggara Barat berada pada sel $\mathrm{V}$ yaitu konsentrasi melalui integrasi horizontal. Dengan konsentrasi melalui integrasi horizontal ini, maka strategi yang dapat diterapkan dalam pengembangan perikanan tangkap dan budidaya adalah strategi dalam pengembangan sumber daya alam, perlu adanya pelatihan dan pembinaan sumber daya manusia dan mengoptimalisasi sumber daya kelautan.

\section{Matriks SPACE}

Matriks SPACE merupakan matriks yang digunakan untuk melihat garis vector positif dan negatif untuk faktor internal dan eksternal. Berdasarkan pada hasil perhitungan analisis pada faktor internal (Gambar 5). Nilai pada garis Horisontal (sumbu X) didapat dari hasil pengurangan antara nilai pada kekuatan (1.488) dan nilai total dari kelemahan (1.156), sehingga memperoleh hasil 0.332 pada garis horizontal (sumbu $\mathrm{X}$ ). Sedangkan hasil pengurangan antara nilai rata-rata dari peluang dan ancaman, dapat digetahui nilai pada garis vertical (sumbu Y) adalah 0.105. Untuk dapat mengetahui secara pasti posisi dari pengembangan pada sub sektor perikanan di Kabupaten Maluku Tenggara Barat dapat dilihat pada diagram yang ada pada Gambar
5. Gambar 5 mengambarkan dimana dalam pengembangan pada sub sektor perikanan (perikanan tangkap dan budidaya rumput laut) berada pada Kuadran I.

Hal ini akan menjelaskan bahwa pengembangan pada subsektor perikanan ini memiliki peluang dan kekuatan sehingga dapat dimanfaatkan dengan baik. Strategi yang harus diterapkan dalam situasi ini adalah mendukung kebijakan pertumbuhan yang agresif (growth oriented strategy).

\section{Matriks SWOT}

Matriks SWOT merupakan dasar dari perumusan strategi pengembangan perikanan di Kabupaten Maluku Tenggara Barat. Strategi ini akan dapat diterapkan kebijakan yang diperlukan untuk mendukung pelaksanaan strategi tersebut dalam mendorong proses pengembangan perikanan di wilayah Maluku Tenggara Barat, dapat dijelaskan strategi pada matriks SWOT sebagai berikut seperti yang terdapat pada Gambar 6.

\section{Berdasarkan pada matriks}

SWOT yang ada pada Gambar 6 dapat dijelaskan bahwa:

\section{Strategi Strength - Opportunities (S - O)}

Strategi yang diterapkan dengan mengandalkan kekuatan yaitu, adanya otonomi daerah dan kebijakan nasional untuk 
pengembangan kegiatan bisnis, menciptakan peluang usaha dengan pelayanan, promosi dan mempermudah ketentuan investor, sehingga dapat memaksimalkan pengolahan sumberdaya alam kelautan yang ada di wilayah Maluku Tenggara Barat secara optimal.

\section{Strategi Strength-Threats $(S-T)$}

Strategi yang dilakukan yaitu; pengembangan tenaga sumber daya manusia yang berkualitas dengan berfokus kepada subsektor perikanan sebagai sector unggulan, sehingga dapat meningkatkan produksi pada subsector perikanan tersebut, penyediaan sarana dan prasarana yang berbasisi teknologi tinggi, serta adanya kebijakan pemerintah yang berfokus pada pengembangan kawasankawasan strategis dan ekonomi khusus yang berbasis pada komoditas unggulan dan strategis untuk mendorong peningkatan kesejahteraan masyarakat.

\section{Strategi Weakness - Opportunities (W - O)}

Pembinaan dan pelatihan Sumber daya Manusia yang tepat sesuai dengan kondisi yang ada, pengembangan sarana dan prasarana sumber daya perikanan dan kelautan yang baik, peningkatan daya saing dan nilai tambah sumber daya perikanan dan kelautan, dukungan dari pemerintah pusat, propinsi dan daerah, dalam pengembangan kelembagaan dan sumber daya manusia secara terintegrasi, meningkatkan tata kelola sumber daya perikanan dan keluatan dalam meraih peluang dipasaran.

\section{Strategi Weakness - Treaths $(\mathrm{W}-\mathrm{T})$}

Strategi yang terapkan yaitu; pelatihan dan pembinaan sumber daya manusia, seperti pemberdayaan masyarakat dengan berbasis pendekatan berbasis subjek peningkatan pengawasan dan penegakan hukum di wilayah perairan, serta penegakan aturan mengenai ketetapan harga pasaran terutama dari susektor perikanan.

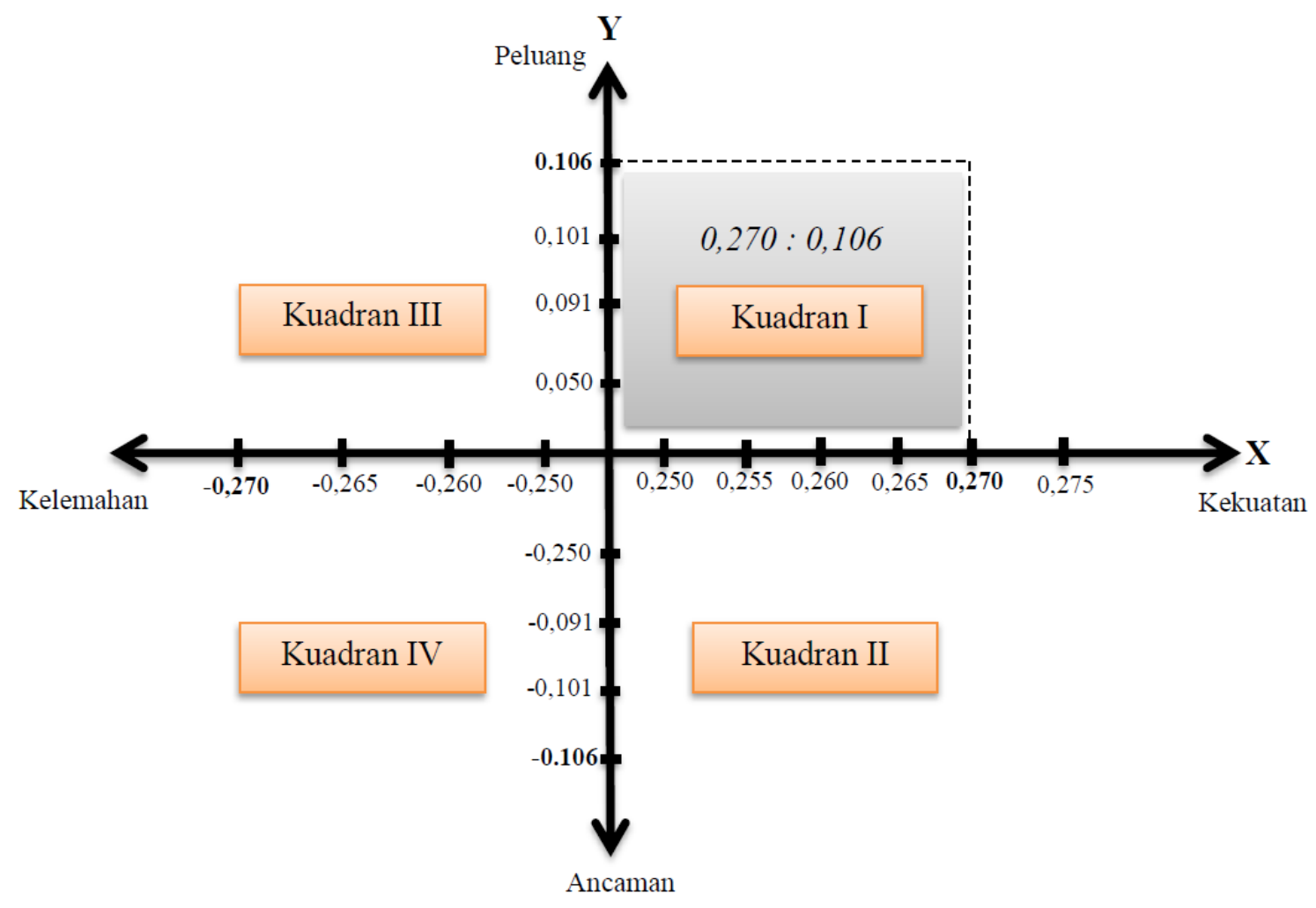

Gambar. 5. Analisis Matriks SPACE 


\begin{tabular}{|c|c|c|}
\hline $\begin{array}{r}\text { IFAS } \\
\text { (Internal Faktor } \\
\text { Strategic Summary) }\end{array}$ & \begin{tabular}{ll} 
& \multicolumn{1}{c}{$\begin{array}{c}\text { Kekuatan } \\
(\text { Strengths/S) }\end{array}$} \\
S1. & Potensi sumber daya alam \\
S2. & Kebijakan Pemerintah \\
S3. & Kondisi kelautan \\
S4. & Tenaga kerja yang handal \\
S5. & $\begin{array}{l}\text { Pengolahan sumber daya } \\
\text { alam }\end{array}$
\end{tabular} & \begin{tabular}{ll} 
& \multicolumn{1}{c}{$\begin{array}{c}\text { Kelemahan } \\
\text { (Weaknesses } / \mathbf{W})\end{array}$} \\
W1. & Sumber daya manusia \\
W2. & Sarana dan prasarana \\
W3. & Penyuluhan petugas lapangan \\
W4. Pemahaman tentang teknologi \\
W5.
\end{tabular} \\
\hline 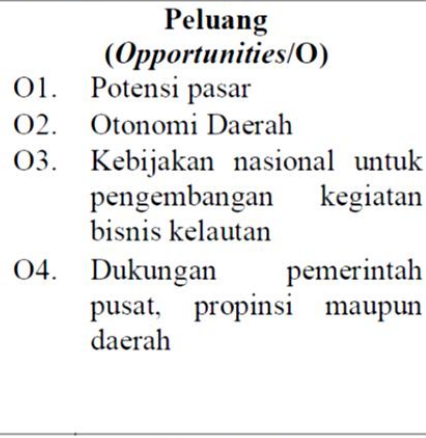 & $\begin{array}{l}\quad \text { Strategi } \boldsymbol{S} \text { - } \boldsymbol{O} \\
\text { Pengembangan SDA yang } \\
\text { berdasarkan pada } \\
\text { kekuatan-kekuatan yang } \\
\text { dimiliki daerah dengan } \\
\text { melihat peluang yang ada. }\end{array}$ & $\begin{array}{l}\text { Strategi } \boldsymbol{W}-\boldsymbol{O} \\
\text { b. Pelatihan, pembinaan SDM tentang } \\
\text { teknologi kepada para nelayan. } \\
\text { c. Peningkatan sarana dan prasarana yang } \\
\text { dapat mendukung pengembangan sektor } \\
\text { perikanan. } \\
\text { d. Peningkatan pembinaan dan pengembangan } \\
\text { SDA di bidang perikanan yang tepat dan } \\
\text { sesuai dengan kondisi yang ada. }\end{array}$ \\
\hline \begin{tabular}{ll} 
& \multicolumn{1}{c}{$\begin{array}{c}\text { Ancaman } \\
(\text { Threats/T) }\end{array}$} \\
T1. & Kondisi alam \\
T2. & Sosial budaya masyarakat \\
T3. & Pencurian ikan \\
T4. & Pasokan energy \\
T5. & Harga produk yang tidak \\
& stabil
\end{tabular} & $\begin{array}{l}\text { Strategi } \boldsymbol{S}-\boldsymbol{T} \\
\text { e. Memaksimalkan } \\
\text { pengembangan dan } \\
\text { pemanfaatan sumberdaya } \\
\text { alam yang terkandung di } \\
\text { Kabupaten Maluku } \\
\text { Tenggara Barat. }\end{array}$ & $\begin{array}{l}\text { g. Menyediakan saran dan prasarana dan } \\
\text { meningkatkan pasokan energy yang } \\
\text { memadai. }\end{array}$ \\
\hline
\end{tabular}

Gambar. 6. Analisis Matriks SWOT untuk Strategi Pengembangan Sub-Sektor Perikanan di Kabupaten Maluku Tenggara Barat, Propinsi Maluku

\section{Pemilihan Alternatif Strategi}

Strategi yang dipilih berdasarkan pada hasil analisis pada Matriks SWOT, dirumuskan dalam empat (4) strategi pokok yang dapat ditetapkan untuk meningkatkan dan mendorong proses pengembangan pada subsektor perikanan yaitu:

a. Pelatihan dan pembinaan Sumber Daya Manusia dalam segala hal terutama teknologi berdasrkan pada kondisi yang ada, serta pengembangan Sumber Daya Alam yang terkandung di daerah Maluku Tenggara Barat, serta men-stabilkan harga pasar.

b. Peningkatan sarana dan prasarana yang dapat mendukung pengembangan sektor perikanan dan meningkatkan pasokan energy yang memadai, serta meningkatkan pengamanan di wilayah perbatasan. c. Memaksimalkan pengembangan dan pemanfaatan sumberdaya alam.

Kebijakan Pemerintah Daerah dalam meningkatkan Sumber Daya Perikanan, sehingga pengolahan dan pemanfaatan Sumber Daya Perikanan dapat dilakukan dengan maksimal dan berkelanjutan.

\section{KESIMPULAN DAN SARAN}

\section{Kesimpulan}

Berdasarkan pada hasil analisis dan pembahasan, maka dapat disimpulkan bahwa: strategi pokok yang dapat ditetapkan untuk meningkatkan dan mendorong proses pengembangan pada sub sektor perikanan di Kabupaten Maluku Tenggara Barat yaitu:

a. Pengembangan kualitas sumber daya manusiapelatihan kegiatan-kegiatan ekonomi masyarakat setempat terutama yang berada dipesisir melalui penguatan 
modal dan pembinaan, serta pening-katan aturan dalam penstabilkan harga pasar.

b. Peningkatan sarana dan prasarana dengan teknologi yang tinggi, serta meningkatkan pengamanan di wilayah perbatasan.

c. Kebijakan pemerintah daerah yang mengarah pada pengembangan subsektor perikanan dalam memaksimalkan pengembangan dan pemanfaatan sumberdaya alam.

\section{Saran}

Dalam meningkatkan pengembangan pada subsektor perikanan di Kabupaten Maluku Tenggara Barat, maka adapun saran untuk penelitian lebih lanjut adalah:

1. Perlu adanya peningkatan kualitas Sumber Daya Manusia yang berkualitas dalam mengembangkan Sumber Daya Alam khusus Sumber Daya Keluatan yang terkandung di Kabupaten Maluku Tenggara Barat.

2. Penyedian sarana dan prasaran yang memadai, sehingga masyarakat rumah tangga perikanan dapat memaksimalkan kemampuan mereka dalam mengolah dan memanfaatkan sumber daya yang terkantung tersebut.

3. Pengembangan kawasan perikanan di Kabupaten Maluku Tenggara Barat perlu dilakukan, sehingga mengarah pada yang berkembang dan mandiri.

4. Kebijakan pemerintah yang selalu terarah pada penegembangan peningkatan Sumber Daya Perikanan.

\section{DAFTAR PUSTAKA}

Adisasmita Rahardjo. 2006. Pembangunan Kelautan dan Kewilayahan. Yogyakarta: Graha Ilmu. 2014. Ekonomi Tata Ruang Wilayah. Yogyakarta: Graha Ilmu.

2014. Pembangunan

Wilayah. Yogyakarta: Graha Ilmu,

Budiharsono Sugeng. 2001. Pembangunan Wilayah Pesisir dan Keluatan. Jakarta: Pradanya Paramita.
Fahmi, Irham. 2013. Manajemen Strategis; Teori dan Aplikasi. Bandun: Alfabeta.

Fauzi Akhmad. 2006. Ekonomi Sumber Daya Alam Dan Lingkungan. Jakarta: Gramedia Pustaka Utama. . 2010. Ekonomi Perikanan: Teori, Kebijakan, dan Pengolahan. Jakarta: Gramedia Pustaka Utama.

Jhingan. M.L. 2013. Ekonomi Pembangunan dan Perencanaan. Jakarta: RajaGrafindo Persada,

Mulyadi. 2007. Sistem Perencanaan dan Pengendalian Manajemen. Jakarta: Salemba Empat.

Nugroho Iwan dan Dahuri Rokhim. 2012. Pembangunan Wilayah; Perspektif Ekonomi, Sosial dan Lingkungan. Jakarta: LP3ES Anggota IKAPI.

Rangkuti Freddy. 2013. Analisis SWOT, Teknik: Membedah Kasus Bisnis. Jakarta: Pustaka Utama,

Rustiadi Ernan, Sunsun Saefulhakim, dan Panuju R. Dyah. 2011. Perencanaan dan Pengembangan Wilayah. Jakarta: Pustaka Obor Indonesia,

Sjafrizal. 2012. Ekonomi Wilayah Dan Perkotaan. Jakarta: PT. Raja Grafindo Persada.

Pembangunan Daerah dalam Era Otonomi. Jakarta: PT. Raja Grafindo Persada.

Tarigan Robinson. 2012. Perencanaan Pembangunan Wilayah; (Ed. Revisi). Jakarta: PT. Bumi Aksara.

2014. Ekonomi Regional (Ed. Revisi). Jakarta: PT. Bumi Aksara.

Widodo, J dan Nurhakim. S. 2002. Konsep Pengelolaan Sumberdaya Perikanan. Disampaikan dalam Training of Trainers on Fisheries Resource Management. Hotel Golden Clarion. 